\title{
PERAN PENDIDIKAN ISLAM BERBASIS KOMPETENSI DALAM PENINGKATAN MUTU PENDIDIKAN DI PTAI
}

\author{
Mardia \\ Dosen UIN Alauddin DPK pada STAI DDI Pinrang \\ Kampus: Jl. Andreas Wahani No. 27 Pinrang \\ Email: mardiasaid@yahoo.com
}

\begin{abstract}
Abstrak:
Tulisan ini membahas tiga persoalan utama yaitu: Pertama, eksistensi dan problematika pendidikan Islam. Kedua, upaya peningkatan mutu pendidikan Islam berbasis kompetensi. Ketiga, peran pendidikan Islam dalam pengembangan kurikulum berbasis kompetensi. Kajian dalam tulisan ini menemukan bahwa problematika utama pendidikan Islam di lembaga pendidikan saat ini adalah hanya dipandang melalui aspek kognitif, tidak dipandang bagaimana peserta didik mengamalkan dalam dunia nyata sehingga belajar agama sebatas menghafal dan mencatat. Hal ini mengakibatkan pelajaran agama menjadi pelajaran teoretis, bukan penghayatan terhadap nilai agama itu sendiri. Maka peningkatan mutu pendidikan Islam diperoleh melalui dua strategi, (1) peningkatan mutu pendidikan yang berorientasi akademis. (2) peningkatan mutu pendidikan yang berorientasi pada life skill yang esensial yaitu pendidikan yang berlandaskan luas, nyata, dan bermakna.
\end{abstract}

\begin{abstract}
:
This paper discusses three main issues: First, the existence and Problems of Islamic Education. Secondly, Improving the Quality of Islamic Education competency-based. Third, the role of Islamic Education in Competency-Based Curriculum Development. Study in this paper found that the main problems of Islamic education in educational institutions today is only seen through the cognitive aspect, not seen how learners to practice in the real world so that the extent of religious study and memorize the notes. This resulted in religious studies lessons not theoretical appreciation of the value of religion itself. So Improving the quality of Islamic education is obtained through two strategies: (1) improving the quality of education that is academically oriented. (2) improving the quality-oriented education is an essential life skill that is broad-based education, real and meaningful.
\end{abstract}

\section{Kata kunci:}

Pendidikan Agama Islam, Peningkatan Mutu, dan Pengembangan Kurikulum

PERSOALAN utama yang dihadapi oleh Perguruan Tinggi Agama Islam (PTAI) saat ini adalah kekurangberhasilannya dalam mencapai dua tujuan pokok pendidikan tinggi seperti yang termaktub dalam PP No. 60 tahun 1999, tentang masalah kualitas lulusan yang dihasilkannya dan sumbangan PTAI pada pengembangan ilmu, dalam hal ini ilmu agama Islam.

Pendidikan Islam dihadapkan pada berbagai tantangan, baik yang bersifat internal maupun eksternal. Pendidikan Islam dianggap kurang berhasil (untuk tidak mengatakan "gagal") dalam menggarap sikap dan perilaku peserta didik serta membangun moral etika bangsa. Fakta menunjukkan bahwa pengaruh budaya asing non- 
edukatif yang mengglobal seperti budaya materialisme, konsumerisme, hedonisme, dan sebagainya semakin kuat. ${ }^{1}$

Pendidikan agama di perguruan tinggi seharusnya merupakan pendamping pada mahasiswa agar bertumbuh dan kokoh dalam karakter agamaisnya sehingga ia dapat tumbuh sebagai cendekiawan yang tinggi moralnya dalam mewujudkan keberadaannya di tengah masyarakat. Tetapi kenyataan sekarang ini, lembaga-lembaga pendidikan tinggi belum sepenuhnya berhasil dalam tugas pembentukan tenaga profesional yang spiritual. Setelah era reformasi, muncul "kesadaran baru" bahwa pendidikan secara umum dan pendidikan agama khususnya, "kurang berhasil" dalam pengembangan moral dan pembentukan perilaku mahasiswa dalam mengantisipasi masalah-masalah etis dan moral era global dan teknik informasi. Tidak terlihat indikasi terjadinya perubahan yang signifikan antara pengetahuan yang tinggi dan tingkat kedewasaan menurut usianya serta pengaruhnya pada perkembangan moralnya.

Pelajaran agama wajib dalam kurikulum sekolah dasar hingga perguruan tinggi. Namun, pelajaran itu sepertinya tidak berdampak pada perilaku tawuran antarpelajar, pemakaian narkoba, dan gejala seks bebas di kalangan muda. Bahkan, diperhadapkan pada problem nasional yang lebih luas seperti pertikaian antaretnis, pertikaian antarumat, kekerasan horizontal, teror, dan budaya korupsi. Karenanya, patut dipertanyakan "Apakah ada efek pendidikan agama?" Semua imoralitas itu berlangsung kian intensif berbarengan dengan kemandulan pendidikan agama di sekolah.

Fenomena pendidikan agama itu tidak lain cerminan problem hidup keberagamaan di tanah air yang telah terjebak ke dalam formalisme agama. Pemerintah merasa puas sudah mensyaratkan agama sebagai mata pelajaran wajib dalam kurikulum. Dosen merasa puas sudah mengajarkan materi pelajaran sesuai kurikulum. Peserta didik merasa sudah beragama dengan menghafal materi pelajaran agama. Semua pihak merasa puas dengan obyektifikasi agama dalam bentuk kurikulum dan nilai rapor atau nilai mata kuliah.

Pelajaran agama di sekolah dalam realitas umumnya hanya diajarkan 3 atau 4 jam pelajaran per pekan saja. Apakah ini yang dimaksudkan untuk memperbaiki akidah serta akhlak anak bangsa? Hal ini lebih pantas dikatakan sebagai formalitas belaka. Tidak ada perbaikan untuk menuju jalan terbaik ataupun hal yang lebih baik. Sebuah pertanyaan kecil membuat kita berpikir, "Adakah yang salah dari wajah pendidikan agama di negeri ini?" Sebagai bangsa yang dikenal religius, seharusnya keberagamaan mempunyai kontribusi untuk mengurangi kejahatan sosial. Nyatanya, belum ada tanda-tanda demikian.

Inilah dampak persaingan global dan krisis multidimensional yang harus sesegera mungkin dicarikan solusinya agar masa depan pendidikan anak bangsa menjadi lebih baik. Berdasarkan identifikasi masalah tersebut di atas, maka masalah yang menjadi inti kajian dalam tulisan ini adalah eksistensi dan problematika pendidikan Islam, upaya peningkatan mutu pendidikan Islam berbasis kompetensi, dan peran pendidikan Islam dalam pengembangan kurikulum berbasis kompetensi. 


\section{PEMBAHASAN}

\section{Kajian Teoretis Peningkatan Mutu Pendidikan Islam}

Mutu dapat diartikan sebagai agregat karakteristik dari produk atau jasa yang memuaskan kebutuhan konsumen/pelanggan. Karakteristik mutu dapat diukur secara kuantitatif dan kualitatif. Mutu telah menjadi isu kritis dalam persaingan modern dewasa ini dan hal itu telah menjadi beban tugas bagi para pimpinan perguruan tinggi. Kualitas (quality) sering disamaartikan dengan mutu. Kualitas sebenarnya telah menjadi bagian dari kehidupan sehari-hari. Akan tetapi, sampai sekarang baik di dunia industri barang maupun industri jasa, belum ada definisi yang sama tentang kualitas. Goetsch dan Davis, ${ }^{2}$ Munro dan Malcolm, ${ }^{3}$ mengibaratkan bahwa "kualitas itu seperti halnya pornografi; sulit didefinisikan, tetapi fenomenanya atau tanda-tandanya dapat dilihat dan dirasakan dalam kehidupan nyata".

Dalam tataran konsep, setiap orang dan organisasi memiliki pengertian tentang kualitas yang berbeda-beda. Deming, salah seorang pioner kualitas menyatakan bahwa kualitas itu memiliki banyak kriteria yang selalu berubah. ${ }^{4}$ Juran mendefinisikan mutu sebagai "fitness for use" (kesiapan untuk bekerja). ${ }^{5}$ Maksudnya suatu produk atau jasa harus dapat memenuhi apa yang diharapkan oleh pemakainya dalam hal kualitas desain, kualitas kesesuaian, ketersediaan, keamanan, dan field use. Tokoh lain adalah Crosby yang menyatakan bahwa kualitas adalah "Conformance to requirement"6, yaitu sesuai dengan yang disyaratkan atau distandarkan. Suatu produk memiliki kualitas apabila sesuai dengan standar kualitas yang telah ditentukan meliputi bahan baku, proses produksi, dan produk jadi. Sementara itu, Isikawa mendefinisikan "Quality is meeting custtomer satisfaction".7 Mutu mengandung makna derajat (tingkat) keunggulan suatu produk (hasil kerja/upaya), baik berupa barang maupun jasa, baik yang tangible maupun yang intangible.

Kualitas memang sesuatu yang tarik-menarik antara sebagai konsep yang absolut dan relatif. Kualitas sekarang ini lebih digunakan sebagai konsep yang absolut. Karena itu, menurut Sallis, kualitas mempunyai kesamaan arti dengan "kebaikan, keindahan, dan kebenaran; atau keserasian yang tidak ada kompromi". ${ }^{8}$ Standar kualitas itu meliputi dua, yaitu: kualitas yang didasarkan pada standar produk/jasa dan kualitas yang didasarkan pada pelanggan (customer). Kualitas yang didasarkan pada produk/jasa, memiliki beberapa kualifikasi: 1) sesuai dengan spesifikasi, 2) sesuai dengan maksud dan kegunaannya, 3) tidak salah atau cacat, dan 4) benar pada saat awal dan selamanya. ${ }^{9}$ Sementara itu, kualitas yang didasarkan pada customer, mempunyai kualifikasi: 1) memuaskan pelanggan (costumer satisfaction), 2) melebihi harapan pelanggan, dan 3) mencerahkan pelanggan. ${ }^{10}$

Meskipun tidak ada definisi mengenai kualitas yang diterima secara universal, dari definisi-definisi yang ada terdapat beberapa kesamaan, yaitu dalam elemen-elemen sebagai berikut: Pertama, kualitas meliputi usaha memenuhi atau melebihi harapan pelanggan. Kedua, kualitas mencakup produk, jasa, manusia, proses, dan lingkungan. Ketiga, kualitas merupakan kondisi yang selalu berubah (misalnya apa yang 
dianggap berkualitas saat ini mungkin dianggap kurang berkualitas pada masa mendatang).

Tetapi pada prinsipnya, tiga guru kualitas menurut Sallis, yaitu Philip Crosby, Edward Deming, dan Joseph Juran menyatakan bahwa komitmen yang harus dibangun dalam setiap diri terhadap kualitas adalah pemahaman bahwa:

Pertama, kualitas merupakan kunci ke arah program yang berhasil. Kurang perhatian terhadap kualitas akan mengakibatkan kegagalan dalam jangka panjang. Kedua, perbaikan-perbaikan kualitas menuntut komitmen menajemen sepernuhnya untuk dapat berhasil. Komitmen kepada kualitas ini harus terus-menerus. Ketiga, perbaikan kualitas adalah kerja keras. Tidak ada jalan pintas atau perbaikan cepat. Menuntut perbaikan budaya bagi organisasi secara keseluruhan. Keempat, perbaikan kualitas menuntut banyak pelatihan. Kelima, perbaikan kualitas menuntut keterlibatan semua karyawan secara aktif dan komitmen mutlak dari manajemen senior. ${ }^{11}$

Komitmen kualitas tersebut di atas, dapat diaplikasikan pada mutu suatu lembaga pendidikan tinggi. Mutu sebagai pencapaian tujuan dari universitas pada umumnya mencakup tri darma lembaga pendidikan dan pengukurannya dilakuan dengan pendekatan exceptional yang memiliki tiga variasi: pertama, mutu sebagai sesuatu yang distinctive, kedua, mutu sebagai sesuatu yang excellent, dan ketiga, mutu sebagai sesuatu yang memenuhi batas standar minimum atau conformance to standard'.

Sementara arti pendidikan Islam secara istilah, para ahli berbeda dalam merumuskannya. Al-Syaibaniy memberikan pengertian sebagai suatu usaha mengubah tingkah laku individu dalam kehidupan pribadinya atau kehidupan kemasyarakatannya dan kehidupan dalam alam sekitarnya melalui proses pendidikan yang berlandaskan nilai-nilai Islam. ${ }^{12}$ Al-Abrasyi mendefinisikan pendidikan Islam adalah mempersiapkan manusia supaya hidup dengan sempurna dan berbahagia, mencintai tanah air, tegap jasmaninya, sempurna budi pekertinya, teratur pikirannya, halus perasaannya, mahir dalam pekerjaannya, manis tutur katanya baik dengan lisan maupun tulisan. ${ }^{13}$ Atau menurut An-Nahlawi, pendidikan Islam mengantarkan manusia pada perilaku dan perbuatan manusia yang berpedoman pada syariat Allah. ${ }^{14}$

Dari pandangan tersebut, penulis berpendapat bahwa pendidikan Islam bukan sekedar transfer of knowledge ataupun transfer of training, melainkan lebih merupakan suatu sistem yang ditata di atas pondasi "keimanan" dan "kesalehan", yaitu suatu sistem yang terkait secara langsung dengan Tuhan. Dengan demikian, dapat dikatakan pendidikan Islam adalah suatu kegiatan yang mengarahkan dengan sengaja perkembangan seseorang sesuai atau sejalan dengan nilai-nilai Islam. Maka sosok pendidikan Islam dapat digambarkan sebagai suatu sistem yang membawa manusia ke arah kebahagian dunia dan akhirat melalui ilmu dan ibadah. Karena pendidikan Islam membawa manusia untuk kebahagian dunia dan akhirat, maka yang harus diperhatikan adalah nilai-nilai Islam tentang manusia, hakekat dan sifat-sifatnya, misi dan tujuan hidupnya di dunia ini dan akhirat nanti, serta hak dan kewajibannya sebagai individu dan anggota masyarakat.

Dalam konteks fitrah, Islam memandang pendidikan sebagai berikut: Pertama, pendidikan harus diorientasikan pada upaya optimalisasi potensi dasar manusia se- 
cara keseluruhan, yaitu mengaktualisasikan segenap potensi yang dimiliki menjadi kompetensi sebagai manusia yang kompeten yaitu sebagai sosok ulil albab ${ }^{15}$ dan sebagai manusia paripurna yaitu manusia yang beriman, berilmu, dan beramal saleh. Kedua, implikasi tentang pandangan kemanusiaan tersebut mengharuskan tujuan pendidikan masa depan yang diarahkan pada pencapaian pertumbuhan kepribadian manusia secara seimbang. Pencapaian kepribadian yang seimbang sangat diperlukan agar prasyarat manusia di masa depan dapat tercapai. Ketiga, terletak pada muatan materi dan metodologi pendidikan karena manusia diakui mempunyai banyak potensi dasar yang terangkum dalam fitrah, maka muatan materi pendidikan harus dapat melingkupi seluruh potensi itu.

\section{Eksistensi dan Problematika Pendidikan Agama Islam}

Secara normatif, Islam telah memberikan landasan kuat bagi pelaksanaan pendidikan. Pertama, Islam menekankan bahwa pendidikan merupakan kewajiban agama dimana proses pembelajaran dan transmisi ilmu sangat bermakna bagi kehidupan manusia. ${ }^{16}$ Kedua, seluruh rangkaian pelaksanaan pendidikan adalah ibadah kepada Allah swt. ${ }^{17}$ Sebagai sebuah ibadah, maka pendidikan merupakan kewajiban individual sekaligus kolektif. Ketiga, Islam memberikan derajat tinggi bagi kaum terdidik, sarjana, dan ilmuwan. ${ }^{18}$ Keempat, Islam memberikan landasan bahwa pendidikan merupakan aktivitas sepanjang hayat (life long education) sebagaimana hadis Nabi yang menjelaskan bahwa menuntut ilmu dari sejak buaian ibu sampai liang kubur. ${ }^{19}$ Kelima, kontruksi pendidikan menurut Islam bersifat dialogis, inovatif, dan terbuka dalam menerima ilmu pengetahuan, baik dari Timur maupun Barat. Itulah sebabnya Nabi Muhammad saw. tidak henti-hentinya untuk memerintahkan umatnya menuntut ilmu walau ke negeri Cina.

Pendidikan agama merupakan upaya sadar untuk menaati ketentuan Allah sebagai guidance dan dasar para peserta didik agar berpengetahuan keagamaan dan handal dalam menjalankan ketentuan-ketentuan Allah secara keseluruhan. Sebagian dari ketentuan-ketentuan Allah itu adalah memahami hukum-hukum-Nya di bumi ini yang disebut dengan ayat-ayat kauniyah. Ayat-ayat kauniyah itu dalam aktualisasinya akan bermakna sunnatullah yang terdapat di alam semesta. Dalam ayat-ayat kauniyah itu, terdapat ketentuan Allah yang berlaku sepenuhnya bagi alam semesta dan melahirkan ketertiban hubungan antara benda-benda yang ada di alam raya. ${ }^{20}$ Untuk memahami hukum-hukum Tuhan itu, manusia perlu menggunakan akalnya yang dibimbing oleh tauhid sebagai pembeda manusia dengan makhluk lain QS. alA'raf/7: 199. Karena itu pula hanya manusia yang dipersiapkan oleh Allah menjadi khalifah di muka bumi QS. al-Baqarah/2: 30.

Peningkatan mutu pendidikan Islam di perguruan tinggi merupakan kelanjutan dari pengajaran yang diterima oleh peserta didik mulai dari tingkat dasar, sekolah menegah pertama dan atas. Namun, berbagai persoalan muncul dan menjadi masalah serius dalam proses pembelajaran pendidikan Islam. Materi yang diajarkan boleh dikatakan sama secara nasional. Banyaknya materi ajar dan kurang bervariasinya metode pengajar dalam menyampaikannya, ditambah lagi dengan alokasi waktu yang ku- 
rang memadai, menjadikan peserta didik (mahasiswa) kurang bergairah dalam menyerap perkuliahan. Kesan yang sering muncul di kalangan mahasiswa adalah mata kuliah "wajib lulus" ini seakan berubah menjadi "wajib diluluskan" karena kalau tidak lulus, akan menjadi hambatan bagi mata kuliah yang lain.

Upaya peningkatan mutu pendidikan Islam, khususnya di perguruan tinggi umum, baik bagi staf pengajarnya, materi kurikulum dan usulan penambahan jumlah SKS-nya sering dilaksanakan. Namun selalu terkendala di lapangan oleh berbagai faktor, misalnya dosen yang belum seragam dalam pemilihan pendekatan pembelajaran karena perbedaan latar belakang disiplin ilmu masing-masing dalam bidang keagamaan. Materi kurikulum yang ditetapkan secara nasional sering kali membuat pengajar tidak mampu melakukan improfisasi sehingga tidak jarang perkuliahan menjadi monoton. Dilihat dari jumlah tatap muka, sudah jelas tidak memadai hanya dengan 2 sks. Berbagai upaya dilakukan untuk menambah jam pelajaran, namun jawaban yang sering didengar adalah "sudah begitu banyak beban mata kuliah mahasiswa yang harus diselesaikan, terutama mata kuliah jurusan, sehingga tidak perlu diberi beban tambahan".

Peran penting agama atau nilai-nilai agama dalam bahasan ini berfokus pada lingkungan lembaga pendidikan, khususnya perguruan tinggi. Salah satu mata kuliah dalam lembaga pendidikan di perguruan tinggi, yang sangat berkaitan dengan perkembangan moral dan perilaku adalah Pendidikan Agama. Mata kuliah Pendidikan Agama pada perguruan tinggi termasuk ke dalam kelompok MKU (Mata Kuliah Umum) yaitu kelompok mata kuliah yang menunjang pembentukan kepribadian dan sikap sebagai bekal mahasiswa memasuki kehidupan bermasyarakat. Mata kuliah ini merupakan pendamping bagi mahasiswa agar bertumbuh dan kokoh moral dan karakter sehingga ia dapat berkembang menjadi cendekiawan yang tinggi moralnya dalam mewujudkan keberadaannya di tengah masyarakat.

Pendidikan tinggi merupakan posisi tertinggi dalam keseluruhan usaha pendidikan nasional dengan tujuan menghasilkan sarjana-sarjana yang profesional, yang bukan saja berpengetahuan luas dan ahli serta terampil dalam bidangnya, serta kritis, kreatif, dan inovatif, tetapi juga beriman dan bertakwa kepada Tuhan yang Maha Esa, berkepribadian nasional yang kuat, berdedikasi tinggi, mandiri dalam sikap hidup dan pengembangan dirinya, memiliki rasa solidaritas sosial yang tangguh, dan berwawasan lingkungan. Pendidikan nasional yang seperti inilah yang diharapkan akan membawa bangsa ini kepada pencapaian tujuan pembangunan nasional yakni masyarakat adil dan makmur yang merata material dan spiritual.

Pokok permasalahan yang menjadi sumber utama problematika pendidikan agama di lembaga pendidikan selama ini hanya dipandang melalui aspek kognitif atau nilai dalam bentuk angka saja, tidak dipandang bagaimana peserta didik mengamalkan dalam dunia nyata sehingga belajar agama sebatas menghafal dan mencatat. Hal ini mengakibatkan pelajaran agama menjadi pelajaran teoretis, bukan pengamalan atau penghayatan terhadap nilai agama itu sendiri. Paulo Freire menegaskan bahwa fungsi pendidikan adalah untuk pembebasan, bukan untuk penguasaan. ${ }^{21}$ Tujuan 
pendidikan adalah untuk menggarap realitas manusia, dan karena itu secara metodologis bertumpu pada prinsip-prinsip aksi dan refleksi total, yakni prinsip bertindak untuk mengubah kenyataan yang menindas dan pada sisi simultan lainnya secara terus-menerus menumbuhkan kesadaran akan realitas dan hasrat untuk mengubah kenyataan yang menindas.

\section{Upaya Peningkatan Mutu Pendidikan Islam Berbasis Kompetensi}

Dalam konteks pendidikan tinggi Islam, persoalan mutu mengacu pada proses pendidikan dan hasil pendidikan. Dalam "proses pendidikan" yang bermutu, terlibat berbagai input, seperti; bahan ajar (kognitif, afektif, atau psikomotorik), metodologi (bervariasi sesuai kemampuan dosen), sarana perkuliahan, dukungan administrasi dan sarana prasarana dan sumber daya lainnya serta penciptaan suasana yang kondusif. Dalam manajemen perguruan tinggi, dukungan kelas berfungsi menyinkronkan berbagai input tersebut atau menyinergikan semua komponen dalam interaksi (proses) pembelajaran, baik antara dosen, mahasiswa dan sarana pendukung di kelas maupun di luar kelas, baik konteks kurikuler maupun ekstra-kurikuler, baik dalam lingkup substansi yang akademis maupun yang non-akademis dalam suasana yang mendukung proses pembelajaran.

Mutu dalam konteks "hasil pendidikan" mengacu pada prestasi yang dicapai oleh lembaga pendidikan pada setiap kurun waktu tertentu. Prestasi yang dicapai atau hasil pendidikan (student achievement) dapat berupa hasil test kemampuan akademis. Dapat pula prestasi di bidang lain seperti prestasi di suatu cabang olah raga, seni atau keterampilan tambahan tertentu seperti komputer, beragam jenis teknik, dan jasa. Bahkan prestasi perguruan tinggi dapat berupa kondisi yang tidak dapat dipegang (intangible) seperti suasana disiplin, keakraban, dan saling menghormati.

Berdasarkan penjelasan tersebut, mutu pendidikan tinggi adalah suatu keberhasilan proses belajar yang menyenangkan dan memberikan kenikmatan kepada pelanggan, bisa berupa mereka yang langsung menjadi penerima produk dan jasa tersebut atau mereka yang nantinya akan merasakan manfaat produk dan jasa tersebut. Maka mutu pendidikan tinggi adalah pencapaian tujuan dan kompetensi lulusan yang telah ditetapkan oleh instansi pendidikan tinggi di dalam rencana strategisnya, atau kesesuaian dengan standar yang telah ditentukan. Secara luas, pengertian mutu pendidikan tinggi dapat mencakup aspek sarana/prasarna, organisasi, manajemen, masukan, proses, dan keluaran yang dapat memuaskan pelanggan internal (dosen, staf administrasi, pengelola perguruan tinggi) serta pelanggan eksternal (mahasiswa, orang tua, masyarakat pengguna serta masyarakat yang lebih luas).

Peningkatan mutu pendidikan Islam yang berbasis kompetensi berorientasi kecakapan hidup (life skill) adalah usaha pendidikan yang memberikan kecakapan personal, kecakapan sosial, kecakapan intelektual, dan kecakapan vokasional untuk bekerja usaha mandiri. Artinya pendidikan Islam yang berbasis kompetensi berorientasi kepada kecakapan hidup harus menunjukkan adanya proses pendidikan yang integral, tidak sekedar memberikan pengetauan agama, tetapi harus membekali peserta didik untuk memiliki nilai-nilai Islam yang dapat diwujudkan dalam kehidupan 
sehari-hari, pancaran dari pribadi yang utuh (integrated personality), tidak sekedar formalistis. tetapi menunjukkan identitas diri.

Peningkatan mutu pendidikan Islam diperoleh melalui dua strategi. Pertama, peningkatan mutu pendidikan yang berorientasi akademis untuk memberi dasar minimal dalam perjalanan yang harus ditempuh mencapai mutu pendidikan yang dipersyaratkan oleh tuntutan zaman. Kedua, peningkatan mutu pendidikan yang berorientasi pada keterampilan hidup (life skill) yang esensial yang dicakupi oleh pendidikan yang berlandaskan luas, nyata, dan bermakna.

Mutu pendidikan tidak saja ditentukan oleh pendidikan tinggi sebagai lembaga pengajaran, tetapi juga disesuaikan dengan apa yang menjadi pandangan dan harapan masyarakat. ${ }^{22}$ Pandangan masyarakat tentang mutu lulusan perguruan tinggi cenderung berkembang seiring dengan perkembangan zaman. Oleh karena itu, perguruan tinggi harus memiliki kontinuitas dalam peningkatan mutu lulusan yang sesuai dengan tuntutan masyarakat dan kebutuhan dunia kerja.

Untuk mencapai peningkatan mutu pendidikan Islam berbasis kompetensi, diperlukan upaya-upaya konkret, antara lain dengan melaksanakan kegiatan berikut ini:

1. Pengintegrasian nilai-nilai agama pada mata pelajaran umum, sebagai upaya pelaksanaan pendidikan berbasis kompetensi.

2. Mengadakan penelitian-penelitian tindakan (action research) untuk mencari metode yang paling tepat dalam pembelajaran yang berdasarkan Al-Qur'an.

3. Pembelajaran berbasis IT agar lebih menarik dan senantiasa aktual.

4. Menyediakan sumber pustaka yang representatif sesuai dengan perkembangan ilmu pengetahuan dan teknologi di setiap jenjang pendidikan.

5. Membuat laboratorium dan media pembelajaran aplikatif yang representatif sesuai dengan standar kompetensi yang ditetapkan, sebagai sarana bagi profesionalisme guru/dosen.

Upaya-upaya konkret tersebut di atas mendorong pihak-pihak yang perduli akan pendidikan untuk mencari paradigma-paradigma baru yang sesuai dengan tuntutan jaman. Tidak mengherankan jika salah satu topik yang ramai dibicarakan dalam bidang pendidikan, baik di Indonesia maupun dunia adalah exellent school educatioan, yang tidak saja mengevaluasi ulang materi pembelajaran dan sumber daya manusia dalam memberi pembelajaran, tetapi juga metode pembelajaran. Bahkan, komisi internasional dunia yaitu The International Commission on Education for the Twenty First Century, dipimpin oleh Jacques Delors, lewat laporannya yang berjudul "Learning the Treasure Within", merekomendasikan agar proses pembelajaran di seluruh dunia pada abad ini diselenggarakan berdasarkan empat pilar. Keempat pilar itu adalah: learning to know, learning to do, learning to be, dan learning to live together.

Rekomendasi ini sangat memengaruhi restrukturisasi kurikulum pendidikan di Indonesia yang dibutuhkan demi terjadinya suatu pembenahan. SK Mendiknas No. 232/U/2000 dan No. 045/U/2002 memperlihatkan terjadinya restrukturisasi yang dimaksud. Dalam kurikulum ini, pendidikan agama menjadi salah satu mata kuliah 
dalam kelompok MPK (Mata Kuliah Pengembangan Kepribadian). Dalam kurikulum yang direstrukturisasi ini, dipergunakan pendekatan baru yang dikenal dengan Kurikulum Berbasis Kompetensi yang sangat mengedepankan kompetensi setiap mata kuliah di perguruan tinggi.

Dalam SK No. 43/DIKTI/Kep./2006 tercantum rambu-rambu pelaksanaan MPK di Perguruan Tinggi, khususnya rumusan visi, misi, standar kompetensi, dan kompetensi dasar. Visi dan misi MPK memberi penekanan kepada pemantapan kepribadian mahasiswa sebagai manusia Indonesia seutuhnya, yang secara konsisten mampu mewujudkan nilai-nilai dasar keagamaan dan kebudayaan.

\section{Peran Pendidikan Islam Berbasis Kompetensi}

Pendidikan Islam berbasis kompetensi bukan sekedar menyampaikan sejumlah teori dan konsep semata. Pendidikan bukan sekedar mengajarkan baca, tulis, dan hitung sematang. Pendidikan bukan sekedar proses transfer ilmu yang hanya membicarakan nilai dan angka-angka dalam ijazah. Pendidikan Islam bukanlah semata pengajaran tantang halal-haram, syarat-rukun, dan baik buruknya sesuatu. Pendidikan Islam pun bukan sekedar proses pembelajaran nilai yang menenkankan pada hapalan dan angka-angka. Lebih jauh dari itu, pendidikan Islam dimaknai sebagai proses pembelajaran tentang bagaimana cara hidup yang benar. Membangun pendidikan Islam dilakukan dengan cara membebaskan peserta didik dari ketidaktahuan, ketidakmampuan, ketidaberdayaan, ketidakbenaran, ketidakjujuran, ketidakadilan, dan dari buruknya hati, akhlak dan keimanan.

Proses pendidikan di lingkungan lembaga perguruan tinggi Islam, diarahkan pada pembentukan kualitas iman, logika, dan akhlak. Terkait dengan itu, pembangunan pendidikan tidak sekedar membangun fasilitas belajar semata karena yang lebih penting adalah melakukan proses pembentukan kematangan dan kualitas kepribadian peserta didik secara utuh dan total.

Seseorang yang dianggap memiliki kompetensi dalam melakukan tugas atau pekerjaan tertentu memerlukan: 1) Basic skills (reading, writing, arithmetic, speaking and listening); 2) Thinking skills (thinking creatively, making decisions, solving problems, visualizing things in the mind's eye, knowing how to learn $\mathcal{E}$ reasoning; 3) Personal quality (Individual responsibility, self-esteem, sociability, self management $\mathcal{E}$ integrity. ${ }^{23}$ Ketiga kemampuan dan kecakapan tersebut harus termuat dalam pengembangan kurikulum Pendidikan Agama.

Menurut Sukmadinata, desain kurikulum adalah menyangkut pola pengorganisasian unsur-unsur atau komponen kurikulum. ${ }^{24}$ Berdasarkan hal tersebut, masalahmasalah yang dihadapi dalam peningkatan mutu pendidikan Islam melalui Kurikulum Berbasis Kompetensi dapat dipecahkan dengan menjawab empat pertanyaan mendasar tentang manajemen kurikulum yaitu: Pertama, "What educational purposes should the school seek to attain?" (Tujuan pendidikan apa yang harus dicapai oleh sekolah?). Kedua, "How can learning experiences be selected which are likely to be useful in attaining these experiences?" (Bagaimana pengalaman belajar yang dipilih berguna dalam pencapaian pengalaman tersebut?). Ketiga, "How can learning experiences be 
organized for effective instruction?" (Bagaimana pengalaman belajar dapat diorganisasikan untuk instruksi yang efektif?). Keempat, "How can the effectiveness of learning experiences be evaluated?" (Bagaimana efektivitas pengalaman belajar dievaluasi?).

\section{Komponen Tujuan atau Standar Kompetensi (Objective)}

Tujuan kurikulum dirumuskan berdasarkan tiga hal. Pertama, perkembangan tuntutan, kebutuhan, dan kondisi masyarakat. Kedua, didasari oleh pemikiran-pemikiran dan terarah pada pencapaian nilai-nilai filosofis, terutama falsafah negara. Ketiga, perumusan tujuan berdasarkan kebutuhan dunia pasar.

Klasifikasi tujuan yang lebih sistematis telah dikemukakan oleh Bloom dan Krathwohl, Bloom dan Masia seperti tertera dalam Zais. ${ }^{25}$ Klasifikasi tersebut terkenal dengan "Taxonomy of Educational Objectives". Domain-domain (wilayah) yang dikembangkan Bloom tersebut dapat dijadikan sebagai alat untuk mengategorikan tujuan kurikulum. Kategori tersebut adalah sebagai berikut: (1) The Cognitif Domain, berkenaan dengan penguasaan kemampuan-kemampuan intelektual atau berpikir; (2) The Affective Domain, berkenaan dengan penguasaan dan pengembangan perasaan, sikap, minat, dan nilai-nilai; dan (3) The Psycomotor Domain, menyangkut penguasaan dan pengembangan keterampilan-keterampilan motorik.

\section{Komponen Isi atau Materi Pembelajaran}

Istilah content atau isi digunakan secara bergantian dengan sejumlah term as subject matter, knowledge, concepts, and ideas. ${ }^{26}$ Persoalan utama dalam komponen isi atau materi pembelajaran (content) adalah what will I teach? Untuk menjawab pertanyaan tersebut, harus ditentukan materi atau pengetahuan apa yang tepat. Pengertian content didefinisikan oleh Saylor and Alexander sebagai berikut:

Content is those facts, observations, data, perceptions, discernments, sensibilities, designs, and solutions drawn from what the minds of men have comprehended from experience and those constructs of the mind that reorganize and rearrage these products of experience into lore, ideas, concepts, generalizations, principles, plans, and solutions'. ${ }^{27}$

Beberapa studi tentang pemilihan materi atau isi, Taba ${ }^{28}$ dan Zais ${ }^{29}$ menekankan bahwa para pembuat kurikulum harus memenuhi beberapa kriteria, yaitu: a) Materi harus sahih dan signifikan (significance). Artinya, menggambarkan pengetahuan mutakhir; b) Relevan dengan kenyataan sosial dan dan memiliki nilai manfaat bagi masyarakat (utility); c) Materi harus seimbang antara keluasan dan kedalaman; d) Materi harus mencakup berbagai ragam tujuan; e) Sesuai dengan kemampuan dan pengalaman peserta didik (human development); f) Materi harus sesuai kebutuhan dan minat peserta didik (interest).

\section{Komponen Strategi pembelajaran (Learning Activities)}

Untuk meningkatkan strategi pembelajaran pendidikan Islam, perlu dilakukan langkah-langkah sebagai berikut: 
a. Mengajar itu bukan mendemonstrasikan kemampuan dosen di hadapan peserta didik, melainkan mengajar itu membantu kesulitan belajar peserta didik. Karena itu, ajari mereka sesuai tingkat kemampuan, minat, kecepatan belajar, dan gaya belajarnya.

b. Dosen selalu menciptakan suasana belajar yang mendorong para peserta didik merasa dirinya penting, berharga, berkemampuan, dan bermartabat.

c. Penyelenggaraan pendidikan Islam dilakukan melalui proses penularan nilai-nilai luhur

d. Pendidikan Islam dikembangkan melalui pendekatan keteladanan dan kepribadian unggul yang dilakukan dengan penuh kecintaan, perhatian, dan kasih sayang.

e. Proses pembelajaran dilakukan dalam suasana belajar yang demokratis, terbuka, hangat, dinamis, dan menyenangkan.

f. Dosen tidak melakukan sesuatu yang dilakukan oleh orang-orang yang telah gagal dalam mendidik.

g. Menghargai sekecil apapun pandangan, pendapat, dan kreativitas peserta didik, serta tabu melakukan penghinaan yang dapat menurunkan semangat dan motivasi belajar peserta didik

Perkuliahan pendidikan Islam dirancang dengan menggunakan berbagai pendekatan seperti inquiry, discovery, problem solving dan lain-lain sesuai dengan karakter kompetensi yang diinginkan. Pendekatan humanis akan melandasi cara pandang terhadap mahasiswa secara general. Dalam implementasinya, pengembangan materi standar perkuliahan diharapkan menggunakan pendekatan contextual teaching-learning (CTL) dan mempertimbangkan life skill. Di samping itu, perkulihan akan didimplementasikan dengan mempertimbangkan berbagai pendektan sebagai berikut:

a. Pendekatan rasa ( $q a l b u)$, yaitu pendekatan untuk menggugah perasaan mahasiswa dalam meyakini kebenaran ajaran Islam yang terkandung dalam Al-Qur'an dan hadis, serta memberi motivasi agar mahasiswa ikhlas mengamalkan ajaran Islam. Hal ini dapat disebut sebagai pendekatan penanaman nilai (inculcation approach), dimana peserta didik mengenal dan menerima sebagai milik mereka sendiri, melalui tahapan menilai, menentukan, dan menerpkan.

b. Pendekatan rasional, yaitu usaha untuk memberikan peranan rasio (akl) dalam memahami dan menerima kebenaran ajaran Islam.

c. Pendekatan fungsional, yaitu usaha untuk menyajikan ajaran Islam dengan menekankan pada segi kemanfaataan bagi mahasiswa dalam kehidupan sehari-hari sesuai dengan tingkat perkembangannya.

d. Pendekatan pembiasaan, yaitu memberikan kesempatan kepada mahasiswa untuk membiasakan sikap dan perilaku baik yang sesuai dengan ajaran Islam.

e. Pendekatan keteladanan, yaitu menampilkan keteladanan, baik yang langsung melalui penciptaan kondisi pergaulan yang akrab antarpersonal warga kampus, perilaku para pendidik dan tenaga kepenidikan lain yang mencerminkan akhlak terpuji, mupun yang tidak langsung seperti suguhan ilustrasi kisah-kisah teladan. 
f. Pendekatan emosional, yaitu tumbuhnya kesadaran untuk menegakkan, memperjuangkan dan bersedia membelanya kapan serta dimana saja.

g. Pendekatan klarifikasi nilai (values clarification approach). Pendekatan ini dimaksudkan untuk menumbuhkan kesadaran dan kemampuan mahasiswa untuk mengidentifikasikan nilai-nilai dari diri sendiri dan orang lain.

Untuk menjamin keaktifan mahasiswa dalam proses perkuliahan, maka dalam pelaksanaan kegiatan perkuliahan, dosen harus menggunakan berbagai strategi yang inovatif dan kreatif serta efektif sehingga dapat mengoptimalkan hasil belajar yang diharapkan. Untuk mengaktifkan perkuliahan, dosen dapat memilih salah satu metode seperti: tanya jawab, diskusi, game, dan pemberian tugas (project). Berbagai metode tersebut -dalam implementasinya- dapat digabungkan/dikombinasikan sesuai dengan karakter kompetensi dan dan materi standar. Yang perlu diperhatikan adalah pendekatan dan metode yang dipilih harus disesuaikan dengan kompetensi standar/dasar, indikator, materi standar, sarana yang ada, dan waktu yang tersedia.

\section{Standar Penilaian (Evaluasi)}

Evaluasi kurikulum dimaksudkan untuk memeriksa tingkat ketercapaian tujuan-tujuan pendidikan yang ingin diwujudkan melalui kurikulum yang bersangkutan. Evaluasi kurikulum pada dasarnya adalah suatu proses untuk mengecek keberlakuan kurikulum yang harus diterapkan dalam empat tahap. Pertama, evaluasi terhadap tujuan atau kompetensi; Kedua, evaluasi terhadap pelaksanaan; Ketiga, evaluasi terhadap efektivitas; Keempat, evaluasi terhadap hasil.

Sistem penilaian yang digunakan dalam kurikulum berbasis kompetensi ini adalah Penilaian Berbasis Kelas (PBK). PBK tersebut merupakan suatu proses pengumpulan, pelaporan, dan penggunaan informasi tentang hasil belajar mahasiswa dengan menerapkan prinsip-prinsip penilaian, pelaksanaan berkelanjutan, bukti-bukti otentik, akurat, dan konsisten sebagai akuntabilitas publik. PBK mengidentifikasikan pencapaian kompetensi dan hasil belajar yang dikemukakan melalui pernyataan yang jelas tentang standar yang harus dan telah tercapai disertai dengan peta kemajuan belajar mahasiswa dan pelaporan.

Penilaian ini dilaksakan secara terpadu dengan kegiatan pembelajaran. Oleh karena itu, ia disebut Penilaian Berbasis Kelas (PBK). PBK dilakukan dengan pengumpulan kerja mahasiswa (portofolio), hasil karya (produk), penugasan (proyek), kinerja (performance), dan tes tertulis (paper and pencil test). Dosen menilai kompetensi dan hasil belajar berdasarkan level pencapaian prestasi. Adapun keberhasilan perkuliahan dalam pembelajaran sistem KBK ini, terlihat dari indikator penilaian yang ada. Yang dimaksud dengan penilaian adalah unsur-unsur pokok yang dapat menjelaskan kemampuan peserta didik setelah menyelesaikan satu satuan pendidikan tertentu. Banyak sekali indikator yang dapat dipilih, akan tetapi yang dipandang paling sensitif adalah hasil ulangan atau hasil tes (formatif, ujian tengah semester, dan ujian akhir semester), penyelesaian tugas-tugas terstruktur, catatan perilaku harian dan laporan aktivitas di luar kampus yang menunjang kegiatan perkuliahan. Dari indika- 
tor-indikator tersebut penilai dapat membuat kesimpulan, sejauh mana mahasiswa telah belajar dan berapa nilai yang adil untuknya.

Acuan yang digunakan dalam penilaian hasil perkuliahan dapat menggunakan dua kriteria, yaitu: kriteria mutlak atau penilaian acuan patokan (PAP) dan kriteria relatif atau penilaian acuan norma (PAN). Penilaian acuan patokan sangat bermanfaat dalam upaya meningkatkan kualitas hasil belajar, sebab mahasiswa diusahakan untuk mencapai standar yang telah ditentukan dan hasil belajar mahasiswa dapat diketahui derajat penilaiannya. Pada penilaian acuan norma, keberhasilan mahasiswa ditentukan oleh kelompoknya. Dalam kurikulum berbasis kompetensi, prestasi mahasiswa ditentukan oleh perbandingan antara pencapaian sebelum dan sesudah perkuliahan (pembelajaran), dan kriteria penguasaan yang ditentukan. Oleh karena itu, dalam PBK lebih tepat apabila menggunakan penilaian acuan norma.

Di samping itu, penilaian otentik perlu dilakuakan terhadap keseluruhan kompetensi yang telah dipelajari mahasiswa melalui kegiatan perkuliahan ditinjau dari dimensi kompetensi yang ingin dicapai. Ranah yang perlu dinilai meliputi ranah kognitif, ranah afektif, dan ranah psikomotor.

Di bawah ini dikemukan beberapa konsep pendidikan Islam yang perlu dikembangkan di Perguruan Tinggi. Pertama, pendidikan Islam menekankan pada nilainilai akhlakul karimah yang berasaskan keimanan, keilmuan, amal saleh dan keikhlasan. Kedua, arah dan kebijakan pendidikan Islam berorientasi pada tuntutan perubahan dan tantangan masa depan, bukan sekedar merujuk pada kepentingan sesaat yang bersifat kuantitatif. Ketiga, menggunakan pendekatan keteladanan, di mana pendidikan Islam diajarkan dan diaplikasikan melalui contoh yang baik. Dosen dan lingkungan (keluarga dan masyarakat) harus berperan sebagai teladan yang patut dicontoh. Ketiga, proses pendidikan tidak terjebak pada transfer pengetahuan semata, tetapi diarahkan pada proses pembentukan jati diri manusia. Yang benar adalah pendidikan keimanan dan bukan pengajaran ilmu pengetahuan tentang keimanan. Yang benar adalah pendidikan keadilan, dan bukan pengajaran ilmu pengetahuan tentang keadilan, dst. Keempat, menggunakan metode yang dapat menumbuhkan suasana belajar yang menyenangkan serta dapat merangsang tumbuhnya semangat, motivasi, disiplin, keuletan, kejujuran, dan kepercayaan diri. Kelima, Sistem evaluasi tidak merujuk pada sesuatu yang bersifat kognitif dalam bentuk angka-angka semata, tetapi lebih bersifat utuh, komprehensif, dan mendalam. Keenam, Nilai-nilai keagamaan dikembangkan melalui proses latihan dan penularan sikap, pemikiran, dan perilaku.

Alternatif dalam pengembangan kurikulum pendidikan Islam berbasis kompetensi dapat ditempuh dengan beberapa cara. Pertama, pengembangan kurikulum pendidikan Islam dengan Total Quality Education (TQE). Menurut Semiawan, TQE memfokuskan pada dua persoalan mendasar: (1) Stimulasi dari koherensi proses pembelajaran sehingga tidak terjadi disintegrasi kurikulum. (2) Analisis kebutuhan berbagai kelompok mahasiswa. Berdasarkan kedua fokus tersebut, TQE lebih menekankan pada proses dan out-put. Kurikulum yang diharapkan dari penerapan TQE adalah kurikulum yang fleksibel sesuai dengan target group analysis (siapa mahasiswa yang 
dihadapi), content analysis (apa sasaran programnya), dan context analysis (kondisi dan situasi bagaimana program diterapkan). Kedua, pendekatan pengembangan pendidikan Islam berbasis kompetensi. Pendekatan yang dapat ditempuh dalam pengembangan kurikulum pendidikan Islam berbasis kompetensi adalah pendekatan teknologik, yaitu program pendidikan yang bertolak dari analisis kompetensi yang dibutuhkan untuk melaksanakan tugas-tugas tertentu. Materi yang diajarkan, kriteria evaluasi sukses, dan strategi belajarnya ditetapkan sesuai dengan analisis tugas (job analysis) tersebut.

\section{SIMPULAN}

Pokok permasalahan yang menjadi sumber utama problematika peningkatan mutu pendidikan agama di lembaga pendidikan selama ini, hanya dipandang melalui aspek kognitif atau nilai dalam bentuk angka saja, tidak dipandang bagaimana peserta didik mengamalkan dalam dunia nyata sehingga belajar agama sebatas menghafal dan mencatat. Hal ini mengakibatkan pelajaran agama menjadi pelajaran teoretis bukan pengamalan atau penghayatan terhadap nilai agama itu sendiri.

Dalam menghadapi otonomi pendidikan, peran yang dimainkan oleh pendidikan Islam adalah: Pertama mampu mengantispasi dampak era globalisasi terhadap prilaku, sikap mental, dan budaya masyarakat daerah setempat, serta memiliki kemampuan berevolusi pada human capital yaitu menjadi sumber daya manusia yang menguasai iptek (to know), dapat mengerjakan tugas secara profesional (to do), serta berperilaku dan berpribadi mandiri (to be have). Kedua, memiliki kontribusi terhadap pembangunan dan pengembangan lembaga-lembaga pendidikan Islam yang tumbuh di daerah setempat, serta pembinaan tenaga kependidikan.

Pendidikan agama sebagaimana telah ditetapkan sebagai mata kuliah wajib pada perguruan tinggi, diharapkan dapat mengembangkan sistem, metode, materi, dan dosen yang berkomptensi pada pengajaran. Dengan demikian, diharapkan kedudukan pendidikan Islam sebagai mata kuliah pengembang kepribadian di perguruan tinggi, mampu menghasilkan mahasiswa yang memiliki profil insan ulil albab (QS. 3:190) yang menggambarkan sosok manusia yang berkompeten, yaitu seorang yang beriman (zikir/afektif), berilmu (pikir/kognitif), dan memanfaatkan ilmunya dalam kehidupan (amal/psikomotor). Dengan demikian, pendidikan Islam berfungsi dan berperan dalam membangun SDM yang kompeten dan berakhlak mulia.

Action Plan dapat dilakukan dengan cara: (1) pengelolaan kurikulum yang dapat membantu mahasiswa mengembangkan potensi diri secara optimal dan sesuai dengan tuntutan pangsa pasar; (2) peningkatan kualitas lulusan sesuai dengan kompetensi yang diharapkan sehingga sesuai dengan kebutuhan yang ada di masyarakat; (3) pencapaian kompetensi dengan berorientasi pada mastery learning yang berbasis pada penilaian otentik dan proses, dan (4) sikap otonomi pengelolaan pembelajaran dengan meningkatkan peranan jurusan dan dosen dalam mengembangkan berbagai inovasi pembelajaran demi peningkatan kualitas lulusan. 


\section{CATATAN AKHIR}

1. Muhaimin, Rekonstruksi Pendidikan Islam dari Paradigma Pengembangan, Manajemen Kelembagaan, Kurikulum hingga Strategi Pembelajaran, Jakarta: PT. RajaGrafindo Persada, 2009, h. 51.

2. D. L Goetsch dan S.B. Davis, Quality Management: Introduction to Total Quality Management for Production, Processing, and Service, New Jersey: Prentice-Hall, Inc., 2000, h. 47.

3. L. Munro dan Malcolm, Menerapkan Manajemen Mutu Terpadu, terj., Jakarta: PT Gramedia, 2006, h. 6.

4. W. E. Deming, Out of the Crisis, Cambridge: Massachusetts Institute of Technology Center for Advanced Engineering Study, 1986, h. 169.

5. J. M. Juran, Juran's Quality Control, New York: McGraw-Hill, 1988.

6. Philip B. Crosby, Quality is Free: The Art Making Quality Certain, New York: McGraw-Hill, 1979, h. 58.

7. Kaoru Ishikawa, What is Total Quality Contrail Englewood Cliffs, New Jersey: Prentice-Hall International Inc.Isikawa, 1985, h. 11.

8. Edward Sallis, Total Quality Management in Education, London: Kogan Page Limited 120 Pentonville Road, 1993, h. 35.

9. Goetsch dan Davis, op. cit., h. 48-49.

10. Edward Sallis, op. cit., h. 22.

11. Ibid., h. 25.

12. O. M. T Al-Syaibaniy, Falsafah Pendidikan Islam, terj. Hasan Langgulung, Jakarta: Bulan Bintang, 1979, h. 399.

13. M. A. Al-Abrasyi, Al-Tarbiyah al-Islamiyah, Dar al-Fikr al-Arabi, t.t, h. 100.

14. Abdurrahman An-Nahlawi, Pendidikan Islam di Rumah Sekolah dan Masyarakat, terj. Shihabuddin, Jakarta: Gema Insani Press, 1995, h. 26.

15. QS Al-Imran/190: 191

16. QS Al-'Alaq/96: 1-5.

17. QS Al-Hajj/22: 54.

18. QS Al-Mujadalah/58: 11, QS Al-Nahl/16: 43.

19. Al-Ghazali, Ihya Ulumuddin, Kairo,1969, h. 5 \& 89.

20. Dep. Agama, IDI EIII, 1996, h.4.

21. Muh. Hanif Dakhiri, Islam dan Pembebasan Paulo Freire, Jakarta: Djambatan dan Penerbit Pena, 2000.

22. Saiful Sagala, Manajemen Strategik dalam Peningkatan Mutu Pendidikan, Bandung: Penerbit Alfabeta, 2007, h. 170.

23. Muhaimin, Pengembangan Kurikulum Pendidikan Agama Islam di Sekolah, Madrasah, dan Perguruan Tinggi, Jakarta: PT. Raja Grafindo Persada, 2007, h. 60-61.

24. Nana Syaodih Sukmadinata, Pengembangan Kurikulum: Teori dan Praktek, Bandung: Remaja Rosdakary, 2007, h. 113.

25. Robert S. Zais, Curriculum Principle and Foundation, New York: Thoms Ciowell Company, 1976, h. 309-310.

26. J. P. Miller dan W. Seller, Curricullum Perspectives and Practice, New York \& London: Longman, 1943), h. 185.

27. Ibid., h. 185. Robert S. Zais, op. cit., h. 324.

28. Hilda Tabah, Curriculum Development: Theory and Practice, New York: Harcourt, Brace and World, 1962, h. 267.

29. Robert S. Zais, op.cit., h. 343. 


\section{DAFTAR PUSTAKA}

Al-Ghazali. Ihya Ulumuddin. Kairo: 1969.

Arifin. Kapita Selecta Pendidikan Umum dan Agama. Semarang: Toha Putra, 1986.

Dakhiri, Muh. Hanif. Islam dan Pembebasan Paulo Freire. Jakarta: Djambatan dan Penerbit Pena, 2000.

Dirjen Perguruan Tinggi Agama Islam. Buku Pendidikan Agama Islam Di Perguruan Tinggi Umum. Jakarta: Depag. RI, 1998.

Fakultas Ilmu Tarbiyah dan Keguruan (FITK) UIN Syahida. Pedoman Akademik Fakultas Tahun 2005/2006. Jakarta: FITK UIN Syarif Hidayatullah, 2005.

Furchan, A., et al. Pengembangan Kurikulum Berbasisi Kompetensi di Perguruan Tinggi Agama Islam. Yogyakarta: Pustaka Pelajar, 2005.

Mardiatmaja, B.S. Tantangan Dunia Pendidikan.Yogyakarta: Penerbit Kanisius, 1996.

Miller, J.P. dan Seller, W. Curricullum Perspectives and Practice. New York \& London: Longman, 1943.

Muhaimin. Arah Baru Pengembangan Pendidikan Islam. Bandung: Nuansa, 2003.

Muhaimin. Pengembangan Kurikulum Pendidikan Agama Islam di Sekolah, Madrasah, dan Perguruan Tinggi. Jakarta: PT. Raja Grafindo Persada, 2007.

Muhaimin. Rekonstruksi Pendidikan Islam dari Paradigma Pengembangan, Manajemen Kelembagaan, Kurikulum hingga Strategi Pembelajaran. Jakarta: PT. RajaGrafindo Persada, 2009. 